UDC 624.154: 624.138.2

\title{
TRAY RESEARCH OF THE STRAIN STATE OF SOIL BASES REINFORCED BY SOIL-CEMENT ELEMENTS UNDER THE STRIP STAMP
}

\author{
Vynnykov Yuriy ${ }^{1}$, Razdui Roman ${ }^{2 *}$, Aniskin Aleksej ${ }^{3}$ \\ ${ }^{1}$ National University «Yuri Kondratyuk Poltava Polytechnic» https://orcid.org/0000-0003-2164-9936 \\ ${ }^{2}$ National University «Yuri Kondratyuk Poltava Polytechnic» https://orcid.org/0000-0002-5819-6056 \\ ${ }^{3}$ University North, Varazdin, Croatia https://orcid.org/0000-0002-9941-1947 \\ *Corresponding author E-mail: romanrazduy@gmail.com
}

\begin{abstract}
Experimental research of weak bases reinforced by vertical soil-cement elements are discribed in this article. Tray research of weak clay bases and bases with percent of reinforcement from $2,1 \%$ to $7,1 \%$ under strip stamp were conduct. As a result of the experiment settlements for each of soil base models were obtained. Characteristic curves of the influence of the reinforcement percentage on the bearing capacity, deformability are given, character of settlements of the investigated soil mass in time at step-increasing loading are shown. It was found that depending on the percentage of reinforcement the critical pressures increased linearly and the values of settlement at critical pressures were determined increased with the base reinforcement percentage. Empirical dependencies were obtained to determine the critical pressures depending on the percentage of reinforcement for the investigated soil conditions. In conclusion, the effectiveness of reinforcing the base of the strip foundations by vertical soil-cement elements was proved.
\end{abstract}

Keywords: loam, rigid strip stamp, settlement, soil base, tray research, vertical soil-cement element.

\section{ЛОТКОВІ ДОСЛІДЖЕННЯ ДЕФОРМОВАНОГО СТАНУ ОСНОВ, АРМОВАНИХ ГРУНТОЦЕМЕНТНИМИ ЕЛЕМЕНТАМИ, ПІД СТРІЧКОВИМ ШТАМПОМ}

\author{
Винников Ю.Л. ${ }^{1}$ Раздуй Р.В. ${ }^{*}$, Аніскін А. ${ }^{3}$ \\ 1,2 Національний університет «Полтавська політехніка імені Юрія Кондратюка» \\ ${ }^{3}$ Північний університет, м. Вараждин, Хорватія \\ *Адреса для листування E-mail: romanrazduy@gmail.com
}

\begin{abstract}
Наведені останні дослідження вітчизняних вчених щодо впливу різних факторів на міцність грунтоцементу. Виявлено, що відсутні експериментальні дані про деформований стан глинистих грунтів під навантаженням від стрічкового штампу. Проведено лоткові випробування жорстким стрічковим штампом слабких глинистих основ без елементів армування та аналогічних основ, посилених грунтоцементними елементами з різним відсотком армування. Описано методику виконання досліджень, характеристика системи навантаження, фізико-механічні властивості елементів армування та грунтової основи. В результаті досліду отримано дані осідань по кожній із моделей грунтової основи та побудовано відповідні графіки осідань. Наведено залежності впливу відсотка армування на несучу здатність та деформативність основи. Проаналізовано залежності осідань дослідного грунтового масиву в часі при ступенево-зростаючому навантаженні. Визначено критичні тиски при різних відсотках армування основи штампу для фізико-механічних характеристик грунту, що розглядається. За результатами побудови графіків встановлено, що критичні тиски на основу залежно від відсотку ії армування підвищуються за лінійною залежністю, а величина осідання, при якій визначалися перший та другий критичні тиски, зі збільшенням відсотку армування основи також зростає. Отримано емпіричні залежності для визначення критичних тисків на основу залежно від відсотку іiі армування з використанням класичних розв'язків Пузиревського та Прандтля для дослідних грунтових умов. Обчислені статистичні коефіцієнти варіації та кореляції для наведених залежностей. На підставі проведеного дослідження доведено ефективність посилення основи стрічкових фундаментів вертикальними грунтоцементними елементами.
\end{abstract}

Ключові слова: вертикальний грунтоцементний елемент, грунтова основа, жорсткий стрічковий штамп, лоткові дослідження, осідання, суглинок. 


\section{Introduction}

In recent decades the method of reinforcing weak bases with vertical soil cement elements (SCE), which can be fabricated by using of jet-grouting or drillingmixing technology, has become popular in the world. The effect of such reinforcement of the bases is that the mechanical characteristics of the soil (modulus of deformation, specific cohesion, etc.) are improved. This increases its load-bearing capacity and reduces its deformability. Reliability, cost-effectiveness, low energy consumption and material consumption are the main factors that substantiate the relevance of researches on the use of soil cement in the arrangement of bases and foundations $[1-6]$.

However, it should be noted that the question of the effectiveness of reinforcing the bases of the strip foundations by SCE and the dependence of the settlement of the building foundations reinforced in this way have not yet been studied enough.

\section{Review of the research sources and publications}

From the practice of geotechnics experimentally and with the use of numerical modeling by the finite element method the effectiveness of the improvement of weak clay soil bases with the help of vertical SCE reinforcement has been proved $[1-10]$.

It has been determined, in particular, from a number of researches conducted by the geotechnical school of Poltava National Technical Yuri Kondratyuk University $[5-7,9,10]$ that over time the strength of the SCE and, consequently, the strength of the reinforced bases increase. Dependences of deformation modules of soilcement mixture on the percentage of cement content and water-cement ratio, soil density, etc. were obtained $[5,6]$.

Based on this, tray stamp-loading tests were conducted with a round rigid stamp and the dependences on the characteristics of the soil base (density of dry soil, depth of arrangement of reinforcing elements, percent of reinforcement, etc.) were determined [7].

\section{Definition of unsolved aspects of the problem}

At the same time, there are no tray tests of bases, which are strengthened with vertical SCE of reinforcement under the rigid strip stamp with the identification of patterns of improving the strengthened by this way weak soil base at steady-growing load.

\section{Problem statement}

Therefore, as the purpose of this work, it was presented the research of the soil bases strain state with variable parameters of the reinforcement in the tray and the analysis of the obtained results of the soil base deformation, which is reinforced with vertical soil cement elements.

\section{Basic material and results}

To achieve exploration objective the following tasks were solved:

- to investigate the strain state of the unreinforced

clay base under the rigid strip stamp;
- to investigate the development of deformations of the clay base reinforced by vertical SCE;

- to compare the strain state of the reinforced and unreinforced bases.

Tray tests were conducted in a metal tray of $3 \mathrm{~mm}$ thick steel sheet with stiffeners made of steel corners (Fig. 1). The front wall is made of transparent organic glass $40 \mathrm{~mm}$ thick. The internal dimensions of the tray are $580 \times 530 \times 560 \mathrm{~mm}$. The test was performed with a rectangular steel stamp measuring $420 \times 35 \mathrm{~mm}$, weighing $67 \mathrm{~N}$. A total of 4 tray experiments were performed. Clay paste was used as the basis for all tray researches.

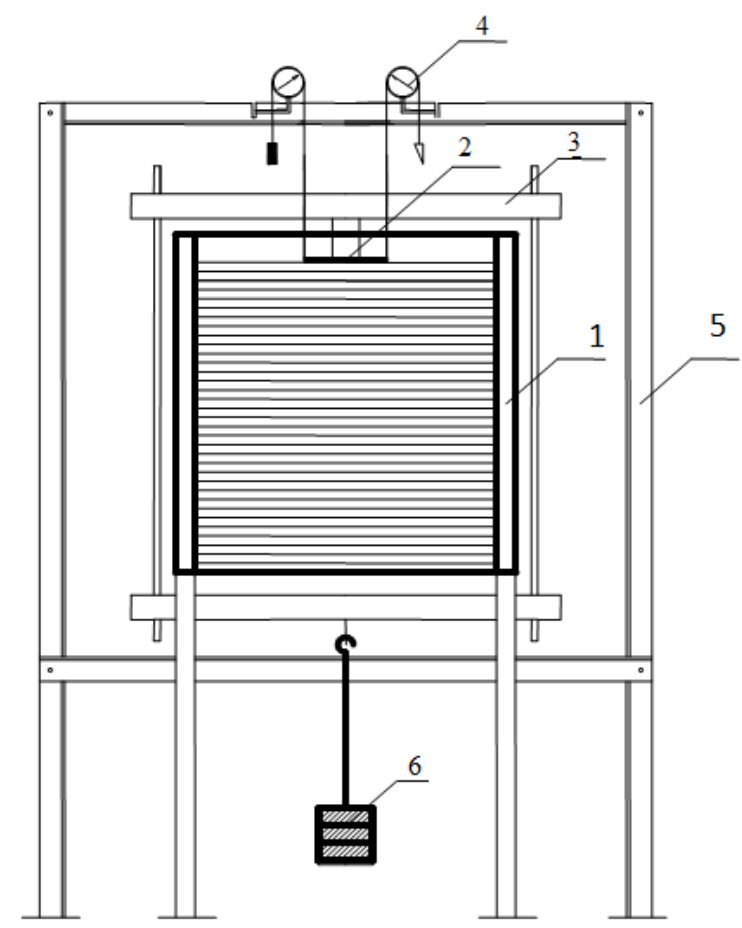

Figure 1 - Representation of the system for laboratory tray tests:

1 - metal tray; 2 - rigid strip stamp; 3 - load system; 4 - deflection indicator;

5 - metal bar for binding of indicators; 6 - cross-beam

In the first case the tests of the clay bases were carried out without reinforcing the CEE. Other tests were performed at different percentages of reinforcement $i$ (ratio of the total volume of the SCE to the total volume of the reinforced array) with a depth of reinforcement of $100 \mathrm{~mm}$.

Based on the experience of reinforcing the bases with vertical SCE [5 - 7] was accepted the variation of the percentage of reinforcement at three levels $i=2,1 \%$; $4.4 \%$ and $7.1 \%$ (Fig. 2).

Clay paste was used to make the basis. The name of the paste corresponds to the heavy floury low-plasticity loam according to the classification of soils. For the preparation of the paste was used a natural soil, that selected from a foundation ditch in Poltava from a depth of $4 \mathrm{~m}$. 


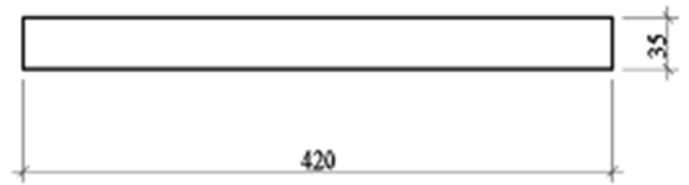

a)

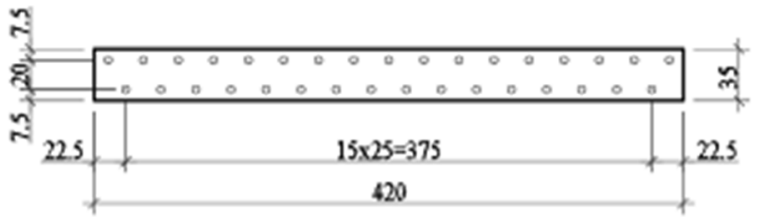

c)

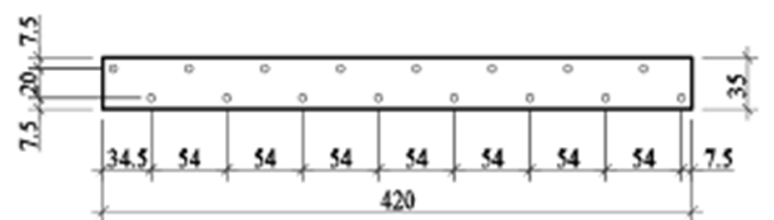

b)

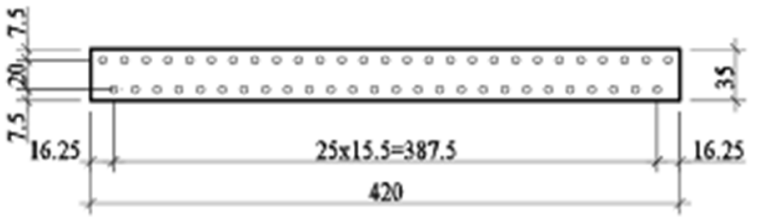

d)

Figure 2 - The different schemes of SCE placement at the basis of the strip stamp depending on the percentage of reinforcement: $a-$ unreinforced base, $b$ - at a percentage of reinforcement of $2.1 \%$, $\mathrm{c}-$ at a percentage of reinforcement of $4.4 \%, \mathrm{~d}-$ at a percentage of reinforcement of $7.1 \%$

The following soil characteristics were determined by laboratory tests: solid particles density $\rho_{s}=2,68 \mathrm{~g} / \mathrm{cm}^{3}$; natural moisture of soil $W=0,205$; moisture of soil at the liquid limit $W_{L}=0,369$; moisture of soil at the plastic limit $W_{P}=0,224$; index of plasticity $I_{P}=0,145$. Based on the required dry soil density and water saturation conditions, the corresponding density and humidity values of the soil samples were calculated for the tests.

The following values of soil physical characteristics are calculated: dry soil density $\rho_{d}=1,45 \mathrm{~g} / \mathrm{cm}^{3}$; natural density $\rho=1,85 \mathrm{~g} / \mathrm{cm}^{3}$; natural moisture of soil $W=0,27$; moisture of soil at the liquid limit $W_{L}=0,369$; moisture of soil at the plastic limit $W_{P}=0,224$; index of plasticity $I_{P}=0,145$; index of liquidity $I_{L}=0,317$; water saturation coefficient $S_{r}=0,85$; void ratio $e=0,85$.

To obtain the required soil characteristics for the experiment, taking into account the required soil moisture and density, an appropriate amount of soil (ground to a homogeneous state) and water for its additional moisture was determined. All components of the soil paste were calculated and selected by weight. The wetting of the required mass of soil powder was carried out by a spray of water with constant stirring of the mixture. The resulting paste was kept in plastic bags for three days to distribute the soil water evenly. In the next phase the paste was placed layer by layer into a tray. The thickness of each layer of clay paste was $15 \pm 2 \mathrm{~mm}$. It was controlled by lines drawn on the glass of tray, and each layer of soil near the front wall of the tray was covered with a layer of chalk $1 \mathrm{~mm}$ thick. Soil compaction was carried out by tamping. During the filling, after completion of the test and before the next filling of the tray with clay paste, soil samples were taken from it to control its physical and mechanical characteristics.

To create a reinforced soil massive in the base of the rectangular strip stamp in the middle of the tray was arranged SCE reinforcement, based on the condition of the uniform placement of elements over the area of the base of the stamp.

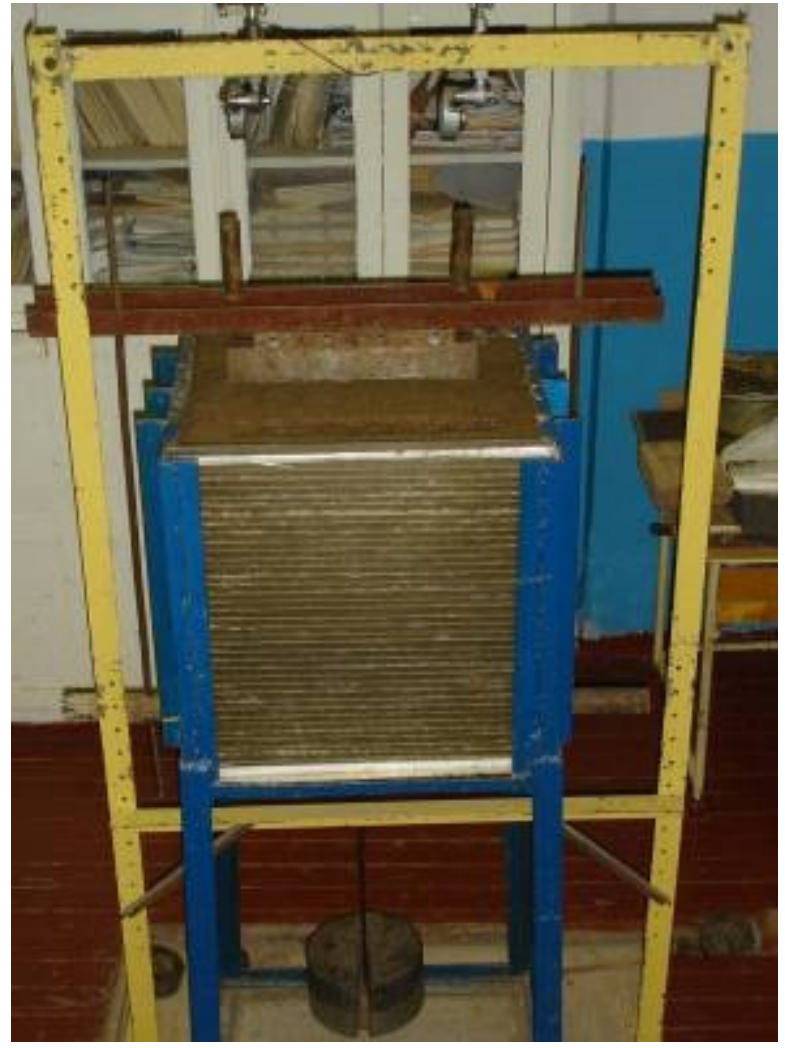

Figure 3 - The tray filled with soil paste for stamping tests during the experiment

Soil-cement elements was made by filling pre-arranged wells with soil cement solution of such composition: soil (heavy floury loam); cement $-20 \%$ form the weight of dry soil; water from the condition of water-cement ratio - 3:1; solution hardening accelerator calcium chloride $\left(\mathrm{CaCl}_{2}\right)$ in the amount of $1 \%$ by weight of water - which allowed to gain seven days' strength of soil-cement after 3 days. To prevent direct contact between the reinforcement elements and the stamp, a $10 \mathrm{~mm}$ thick layer of crushed stone of 2-4 $\mathrm{mm}$ fraction was poured over the reinforced massive. 
The load on the stamp was transmitted through a loading system consisting of a steel channel and a steel pipe. Channel was mounted on top of the stamp (the load was transmitted through a steel prism of dimensions $250 \times 35 \times 70 \mathrm{~mm}$ ). The pipe was hung to the channel using two levers as a suspension. A traverse was attached to it, on which crate cargoes were loaded. The own weight of the loading system together with the rectangular strip stamp was $282 \mathrm{~N}$.

The pressure on the base was applied in stages: the initial degree was equal to the weight of the load system; each subsequent was 200 N. Each degree of pressure was maintained until the conditional stabilization of the basis settlements, the criterion of which was taken not exceeding the settlement of the stamp $0,1 \mathrm{~mm}$ in the last 2 hours of observations. Deformation fixation was performed after $1 \mathrm{~min}, 5 \mathrm{~min}, 15 \mathrm{~min}, 30 \mathrm{~min}$, $60 \mathrm{~min}$. and every 60 minutes after applying the next degree of pressure. The tests were stopped after reaching the basis of the limit of bearing capacity, which was manifested in the rapid increase of deformations without stabilizing.
In the course of conducting a series of stamp tests of the unreinforced and reinforced soil cement bases, the values of the average settlements of the basis of the stamp from the step-increasing pressure were obtained (Table 1). During the fixation of deformations in time the characteristic curves of settlements development of the basis of rigid strip stamp at each degree of pressure at different percentages of reinforcement of the basis are constructed.

Fig. 4 illustrates the dependence of the settlement of the basis of the rigid rectangular strip stamp at step load on pressure. Curve (1) shows an increase in settlement of the unreinforced soil massive from pressure, others show dependencies for the reinforced soil bases with percentages of reinforcement: $2.1 \%$ (2); 4.4\% (3) and $7.1 \%$ (4). As we can see from the graphs, the strength of the soil base increases significantly as the reinforcement parameters increases. The designations $F_{1}$ and $F_{2}$ in Fig. 4 are characteristic points corresponding to the first and second critical forces, respectively.

Table 1 - Development of settlements of the basis of the stamp depending on the reinforcement percentage

\begin{tabular}{|c|c|c|c|c|c|c|}
\hline \multirow{2}{*}{$\begin{array}{l}\text { The degree of step- } \\
\text { increasing loading }\end{array}$} & \multirow{2}{*}{$\begin{array}{l}\text { Load, } \\
\text { kN }\end{array}$} & \multirow{2}{*}{$\begin{array}{l}\text { Pressure, } \\
\qquad \mathrm{kPa}\end{array}$} & \multicolumn{4}{|c|}{ Average settlement at the percentage of reinforcement, $\mathrm{mm}$} \\
\hline & & & $0,0 \%$ & $2,1 \%$ & $4,4 \%$ & $7,1 \%$ \\
\hline Initial conditions & 0,000 & 0,0 & 0,00 & 0,00 & 0,00 & 0,00 \\
\hline Loading system & 0,172 & 11,7 & 0,36 & 0,27 & 0,08 & 0,11 \\
\hline 1 degree & 0,372 & 25,3 & 1,42 & 0,73 & 0,34 & 0,29 \\
\hline 2 degree & 0,568 & 38,6 & 4,50 & 1,68 & 1,16 & 0,96 \\
\hline 3 degree & 0,768 & 52,2 & 6,27 & 2,36 & 1,61 & 1,42 \\
\hline 4 degree & 0,979 & 66,6 & 10,27 & 4,30 & 2,40 & 2,08 \\
\hline 5 degree & 1,178 & 80,2 & 11,53 & 6,06 & 3,76 & 2,57 \\
\hline 6 degree & 1,378 & 93,7 & 26,29 & 9,11 & 4,40 & 3,04 \\
\hline 7 degree & 1,578 & 107,3 & - & 10,98 & 6,75 & 4,06 \\
\hline 8 degree & 1,773 & 120,6 & - & 12,25 & 6,97 & 5,24 \\
\hline 9 degree & 1,971 & 134,1 & - & 17,03 & 9,19 & 7,77 \\
\hline 10 degree & 2,170 & 147,6 & - & - & 10,98 & 9,74 \\
\hline 11 degree & 2,370 & 161,2 & - & - & 13,90 & 11,86 \\
\hline 12 degree & 2,570 & 174,8 & - & - & 15,20 & 13,08 \\
\hline 13 degree & 2,765 & 188,1 & - & - & 19,72 & 15,69 \\
\hline 14 degree & 2,965 & 201,7 & - & - & - & 17,05 \\
\hline 15 degree & 3,165 & 215,3 & - & - & - & 19,44 \\
\hline 16 degree & 3,365 & 228,9 & - & - & - & 24,41 \\
\hline
\end{tabular}




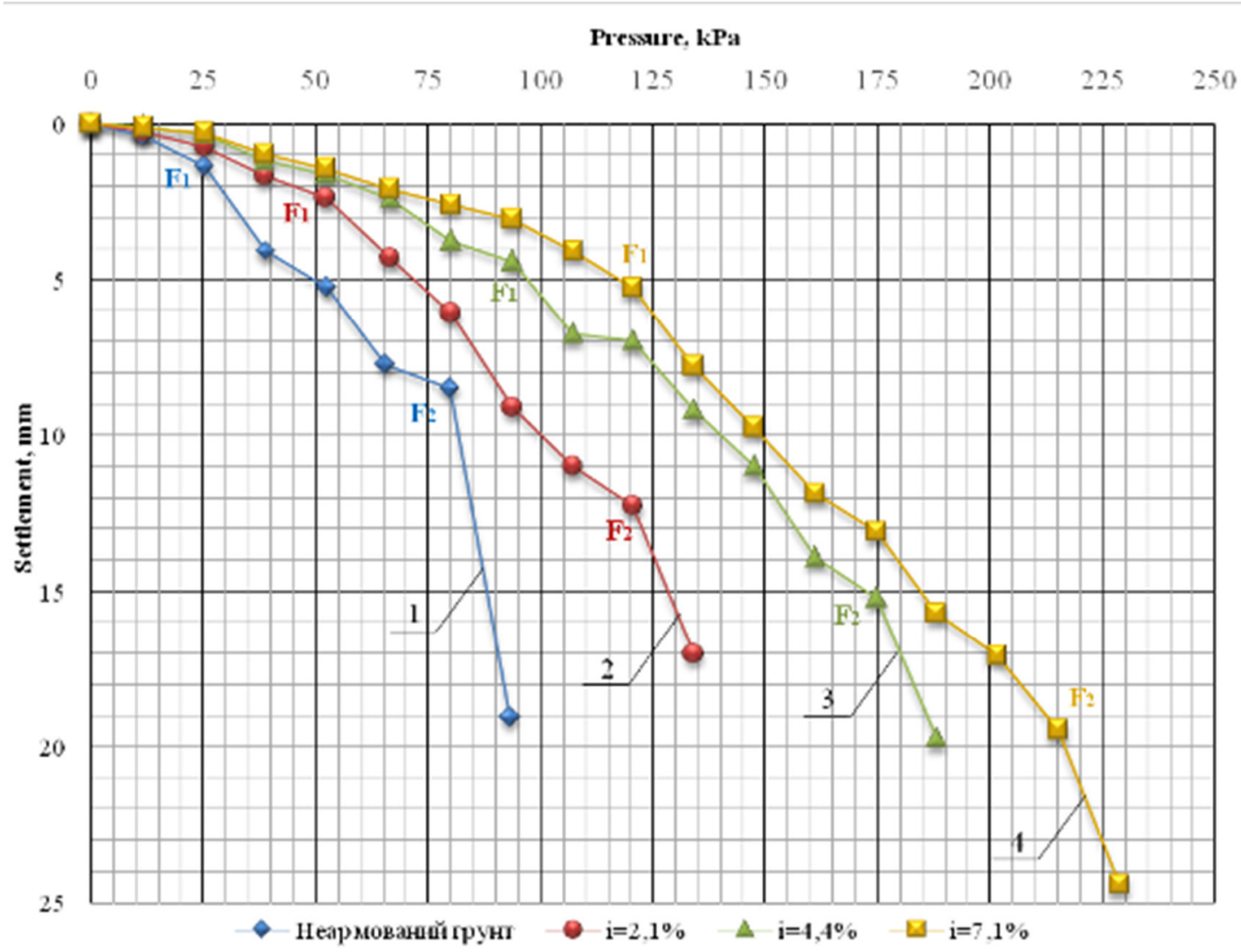

Figure 4 - Graph of dependence of settlements of the rigid strip stamp base on the pressure at step load: $a$ - unreinforced base, $b$ - at a percentage of reinforcement of $2.1 \%$,

$\mathrm{c}-$ at a percentage of reinforcement of $4.4 \%, \mathrm{~d}-$ at a percentage of reinforcement of $7.1 \%$;

$\mathrm{F}_{1}$ - the first critical force; $\mathrm{F}_{2}-$ the second critical force

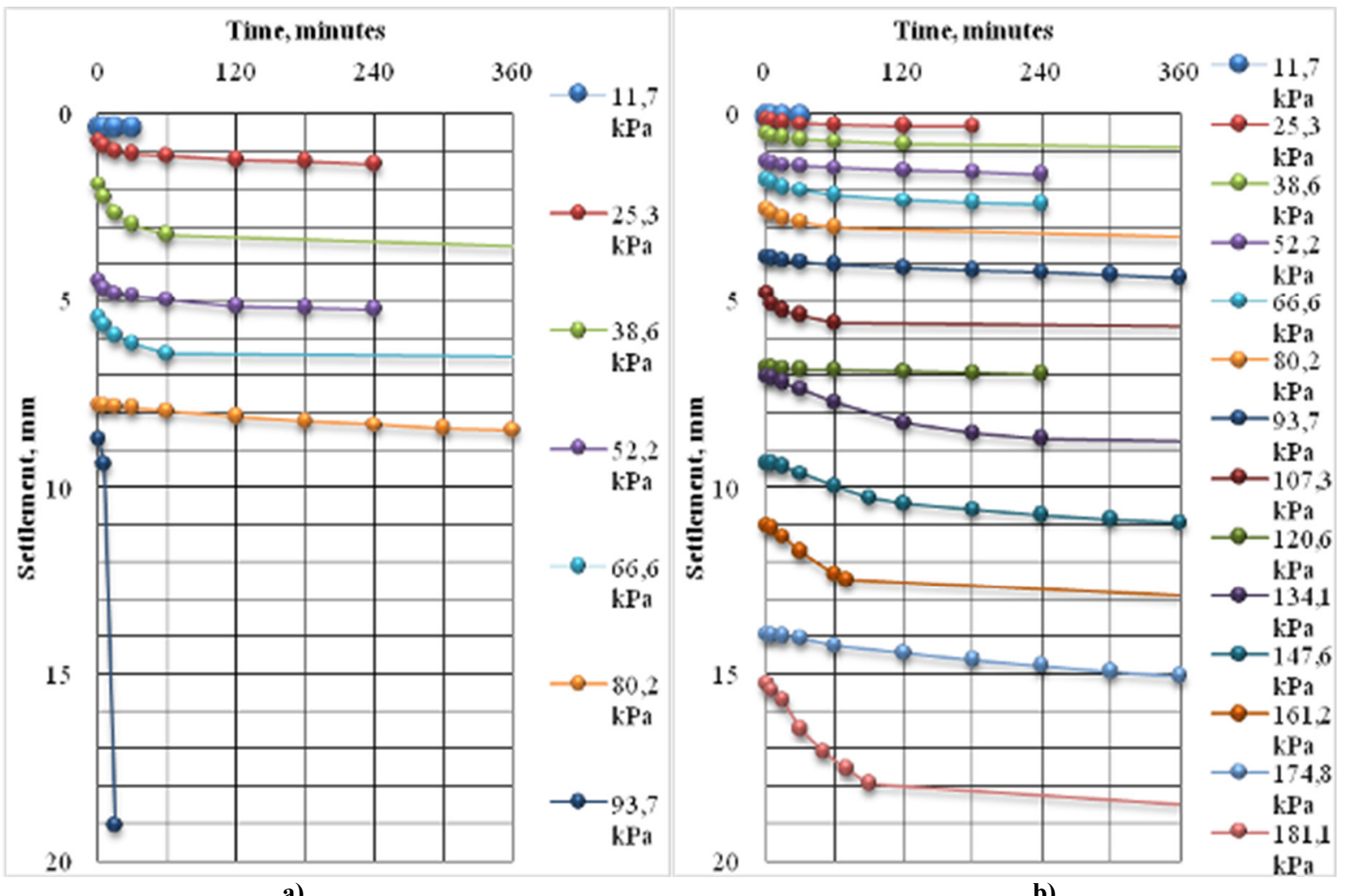

Figure 5 - Graph of settlements in time:

$\mathrm{a}$ - unreinforced base, $\mathrm{b}$ - at a percentage of reinforcement of $4.4 \%$ 
Fig. 5a shows a graph of the development of settlements of the unreinforced stamp base in time at step load. In Fig. 5b we can see a graph of the development of settlements of the reinforced soil massive in time at step load on the example of settlement of the basis reinforced by SCE with a percentage of reinforcement $i=$ $4.4 \%$. The stabilization of the reinforced base at the same pressure occurs faster than the unreinforced one and increases with the increase of the percentage of reinforcement. Fig. 6 shows a graph of the settlements of the soil base at $i=4.4 \%$ at step-increasing load, taking into account the unloading of the system.

\section{Pressure, kPa}

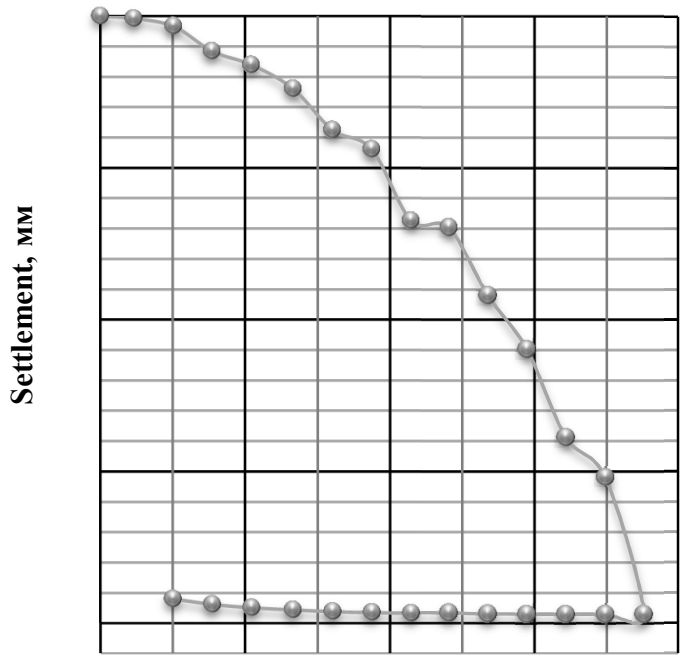

Figure 6-Graph of settlements in time the base at a percentage of reinforcement of $4.4 \%$ with the unloading of the system

From the graph of the dependence of the base settlements under the rigid strip stamp on the pressure, certain regularities have been identified for its improvement by the SCE. Analyzing the experimental dependences of the settlements of the reinforced bases at stepping-increasing pressure (Fig. 3), it can be found that the bearing capacity (strength) of the bases increases with the percentage of soil reinforcement.

To identify the influence of the percentage of reinforcement on the change in bearing capacity on each of the graphs found characteristic points - the critical forces $F_{1}$ and $F_{2}$, which distinguish the transition from a linear relationship between stresses and deformations of the base (first and second critical pressures) [3]. It is known that the first critical pressure $\mathrm{p}_{1}$ corresponds to the end of the compaction phase when no boundary condition is yet emerging at any point of the soil base and the second critical pressure on the soil is considered the maximum boundary pressure $\mathrm{p}_{2}$ at which the full load carrying capacity of the soil takes place.

At characteristic points, the least-squares method found approximate dependences of the first critical pressure on the percentage of soil reinforcement (Fig. 7). According to the obtained values of the first critical pressure by the simplified Puzyrevsky formula, the specific clutch values for the soil under consideration were determined. This formula for perfectly connected clay soils $(\varphi \approx 0 ; \mathrm{c} \neq 0)$ has the form

$$
\mathrm{p}_{1}=\pi \mathrm{c}+\gamma \mathrm{d} \text {. }
$$

The Prandtl solution was adopted to determine the specific cohesion by 2 critical pressure

$$
\mathrm{p}_{2}=5,14 \mathrm{c}+\gamma \mathrm{d},
$$

where $c$ - specific cohesion; $\gamma$ - soil density; $d$ - foundation depth.

With the given parameters of the soil base, the dimensions of the stamp and the height of the reinforcement, the bearing capacity of the base increases with the percentage of reinforcement (Table 2).

Table 2 - Determined critical pressures with varying parameters of the percentage of base reinforcement

\begin{tabular}{|c|c|c|c|}
\hline \multicolumn{2}{|c|}{$\begin{array}{r}\text { The percentage of rein- } \\
\text { forcement } i, \%\end{array}$} & $\begin{array}{c}\text { The first } \\
\text { critical pres- } \\
\text { sure }\end{array}$ & $\begin{array}{c}\text { The second } \\
\text { critical pres- } \\
\text { sure }\end{array}$ \\
\hline \multirow{2}{*}{0,0} & $\mathrm{P}, \mathrm{kPa}$ & 25,3 & 79,9 \\
\cline { 2 - 4 } & $\mathrm{s}, \mathrm{mm}$ & 1,35 & 8,48 \\
\hline \multirow{2}{*}{2,1} & $\mathrm{P}, \mathrm{kPa}$ & 52,2 & 120,3 \\
\cline { 2 - 4 } & $\mathrm{s}, \mathrm{mm}$ & 2,36 & 12,25 \\
\hline \multirow{2}{*}{4,4} & $\mathrm{P}, \mathrm{kPa}$ & 93,7 & 174,8 \\
\cline { 2 - 4 } & $\mathrm{s}, \mathrm{mm}$ & 4,40 & 15,20 \\
\hline \multirow{2}{*}{7,1} & $\mathrm{P}, \mathrm{kPa}$ & 120,6 & 221,3 \\
\cline { 2 - 4 } & $\mathrm{s}, \mathrm{mm}$ & 5,24 & 19,44 \\
\hline
\end{tabular}

The first critical pressure for unreinforced weak soil was approximately $25.3 \mathrm{kPa}$, for a reinforced base with a reinforcement percentage of $2.1 \% ; 4.4 \% ; 7.1 \%$ is 52.2 $\mathrm{kPa}, 93.7 \mathrm{kPa}$ and $120.6 \mathrm{kPa}$, respectively. The second critical pressure was $79.9 \mathrm{kPa}, 120.3 \mathrm{kPa}, 174.8 \mathrm{kPa}$ and $215.3 \mathrm{kPa}$, respectively. In this case, the critical force $F_{1}$ corresponds to settlement of 1.4-5.2 mm, and $\mathrm{F}_{2}-8.5-19.4 \mathrm{~mm}$, depending on the percentage of reinforcement of the base.

Table 3 - The results of the approximation of the experimental data of the dependence of the critical pressures on the base

\begin{tabular}{|c|c|c|c|}
\hline \multicolumn{2}{|c|}{$\begin{array}{c}\text { The first critical pres- } \\
\text { sure, } \mathrm{kPa}\end{array}$} & $\begin{array}{c}\text { The second critical pres- } \\
\text { sure, } \mathrm{kPa}\end{array}$ \\
\hline \multicolumn{2}{|c|}{$p_{1}=25,97+13,81 i$} & \multicolumn{2}{|c|}{$p_{2}=81,57+19,43 i$} \\
\hline $\begin{array}{c}\text { correlation } \\
\text { coefficient }\end{array}$ & $\begin{array}{c}\text { variation } \\
\text { coefficient }\end{array}$ & $\begin{array}{c}\text { correlation } \\
\text { coefficient }\end{array}$ & $\begin{array}{c}\text { variation } \\
\text { coefficient }\end{array}$ \\
\hline$r=0,995$ & $v=0,054$ & $r=0,996$ & $v=0,031$ \\
\hline
\end{tabular}


As the percentage of base reinforcement increased, the settlement value at which the critical pressures $p_{1}$ and $\mathrm{p}_{2}$ on the base were determined increased. The values of the statistical indices (correlation coefficient $r$ and variation coefficient $v$ ) of the obtained dependences indicate an increase in the value of the first critical pressure with increasing percentage of reinforcement by linear dependence (Fig. 7). In the table 3 shows the empirical equations of these dependencies and the statistical accuracy of the approximation of the data for these equations.

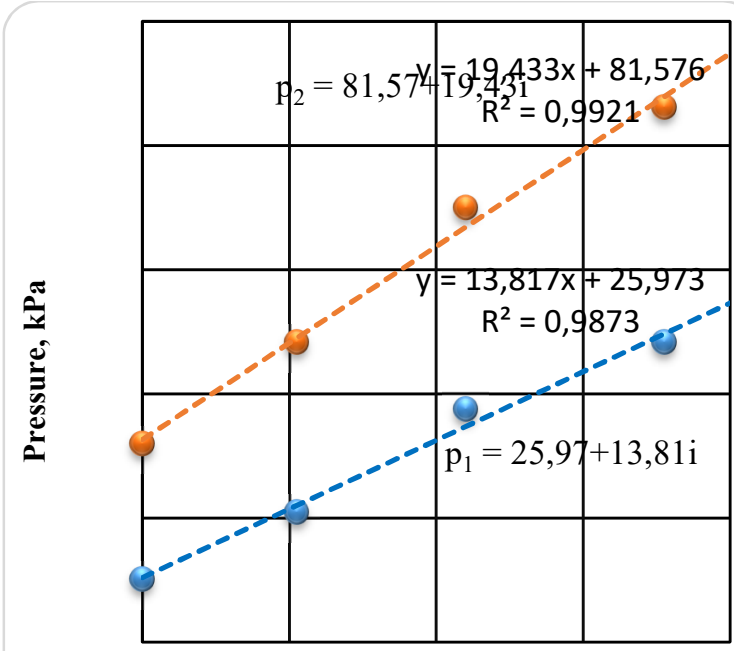

Reinforcement ratio, \%

Figure 7 - Dependences of the critical pressure of the soil base bearing capacity on the ratio of reinforcement

The results of determining the specific cohesion for the reinforced and unreinforced bases of the rigid strip stamp are summarized in Table 4. It should be noted that the obtained value of the specific cohesion on the second critical pressure is higher, and as the percentage of reinforcement of the base increases the difference in values between the solutions of Prandtl and Puzyrevsky formulas decreases.
Table 4 - Specific cohesion, determined by the critical pressure on the base

\begin{tabular}{|c|c|c|c|}
\hline \multicolumn{2}{|c|}{ Soil base } & \multicolumn{2}{c|}{$\begin{array}{c}\text { Specific cohesion, } \mathrm{kPa} \\
\text { (determined by critical } \\
\text { pressures })\end{array}$} \\
\hline $\begin{array}{c}\text { Dry soil } \\
\text { density, } \\
\Gamma / \mathrm{cm}^{3}\end{array}$ & $\begin{array}{c}\text { Reinforcement, } \\
\%\end{array}$ & $\begin{array}{c}\text { the first } \\
\text { critical } \\
\text { pressure }\end{array}$ & $\begin{array}{c}\text { the second } \\
\text { critical } \\
\text { pressure }\end{array}$ \\
\hline \multirow{3}{*}{1,45} & 0,0 & 8,3 & 15,8 \\
\cline { 2 - 4 } & 2,1 & 17,5 & 23,8 \\
\cline { 2 - 4 } & 4,4 & 27,6 & 32,5 \\
\cline { 2 - 4 } & 7,1 & 39,5 & 42,7 \\
\hline
\end{tabular}

\section{Conclusions}

From the analysis of tray researches of pressure-settlement dependence, we can conclude that the soil base under the strip foundations is being improved by the method of reinforcing by SCE, in particular:

1. From the graph of settlement on load it can be observed that the parameters of the soil base and the height of reinforcement of the first and second critical pressures of the system "reinforced base - the strip foundation" increase in the parameters specified in this work.

2. The first and second critical pressures, depending on the percentage of reinforcement of the base, increases linearly.

3 . With the percentage of base reinforcement increment, the amount of sedimentation at which the first and second critical pressures on the base were determined increased.

4. The determination of the specific cohesion of the soil from the obtained dependences on the first and second critical pressures due to the Puzyrevsky and Prandtl formulas for reinforced soil differs, but within the tolerable error.

\section{References}

1. Briaud, J.-L. (2013). Geotechnical Engineering: Unsaturated and Saturated Soils. Wiley.

2. Denies, N. \& Lysebetten, G.V. (2012). Summary of the short courses of the IS-GI 2012 latest advances in deep mixing. Proc. of the Intern. Symposium on Ground Improvement IS-GI. Brussels.

3. Dhaybi, M., Grzyb, A., Trunfio, R. \& Pellet, F. (2012). Foundations reinforced by soil mixing: Physical and numerical approach. Proc. of Intern. Symp. "Recent research, advances \& execution aspects of ground improvement works", Vol. III. Brussels.

4. Fleming, K., Weltman, A., Randolph, M., Elson, K. (2008). Piling Engineering. London- New York: Taylor\&Francis.

5. Zotsenko, N., Vynnykov, Yu. \& Zotsenko V. (2015). Soil-cement piles by boring-mixing technology. Energy, energy saving and rational nature use. Oradea University Press.
1. Briaud, J.-L. (2013). Geotechnical Engineering: Unsaturated and Saturated Soils. Wiley.

2. Denies, N. \& Lysebetten, G.V. (2012). Summary of the short courses of the IS-GI 2012 latest advances in deep mixing. Proc. of the Intern. Symposium on Ground Improvement IS-GI. Brussels.

3. Dhaybi, M., Grzyb, A., Trunfio, R. \& Pellet, F. (2012). Foundations reinforced by soil mixing: Physical and numerical approach. Proc. of Intern. Symp. "Recent research, advances \& execution aspects of ground improvement works", Vol. III. Brussels.

4. Fleming, K., Weltman, A., Randolph, M., Elson, K. (2008). Piling Engineering. London- New York: Taylor\&Francis.

5. Zotsenko, N., Vynnykov, Yu. \& Zotsenko V. (2015). Soil-cement piles by boring-mixing technology. Energy, energy saving and rational nature use. Oradea University Press. 
6. Зоценко, М.Л., Винников, Ю.Л., Зоценко, В.М. (2016). Бурові трунтоцементні палі, які виготовляються за бурозмішувальним методом. Харків: Мадрид.

7. Марченко, В.I. (2012). Напружено-деформований стан армованих за бурозмімувальною технологією слабких глинистих основ з урахуванням чиннику часу (Автореф. дис. ... канд. техн. наук). ПолтНТУ, Полтава.

8. Ильичев, В.А., Мангушев, Р.А. (Ред.). (2014). Сnравочник геотехника. Основания, фундаменты и подземные сооружения. Москва: Изд-во АСВ.

9. Zotsenko, M.L., Vynnykov, Yu.L., Bondar, V.O. \& Novokhatniy, V.G. (2018). Monitoring of the soil-cement piles buildings settlements. Academic Journal. Series: Industrial Machine Building, Civil Engineering, 1(50), 159-166. https://doi.org/10.26906/znp.2018.50.1071

10. Vynnykov, Yu., Voskobiinyk, O., Kharchenko, M. \& Marchenko, V. (2017). Probabilistic analysis of deformed mode of engineering constructions soil-cement grounds. Proc. of the $6^{\text {th }}$ Intern. Scientific Conf. «Reliability and Durability of Railway Transport Engineering Structures and Buildings»» (Transbud-2017).

https://doi.org/10.1051/matecconf/201711602038
6. Zotsenko, N.L., Vynnykov, Yu.L. \& Zotsenko, V.M. (2016). Soil-cement piles by drilling-mixing technology. Kharkiv: Madrid Edition.

7. Marchenko, V.I. (2012). The stress-stain state of weak clay bases reinforced by drilling-mixing technology, taking into account the time factor (Master's thesis). PoltNTU, Poltava.

8. Ilichev, V.A. \& Mangushev, R.A. (Ed.). (2014). Geotechnical reference book. Bases, foundations ans underground structures. Moscow: ASV.

9. Zotsenko, M.L., Vynnykov, Yu.L., Bondar, V.O. \& Novokhatniy, V.G. (2018). Monitoring of the soil-cement piles buildings settlements. Academic Journal. Series: Industrial Machine Building, Civil Engineering, 1(50), 159-166.

https://doi.org/10.26906/znp.2018.50.1071

10. Vynnykov, Yu., Voskobiinyk, O., Kharchenko, M. \& Marchenko, V. (2017). Probabilistic analysis of deformed mode of engineering constructions soil-cement grounds. Proc. of the $6^{\text {th }}$ Intern. Scientific Conf. «Reliability and Durability of Railway Transport Engineering Structures and Buildings» (Transbud-2017).

https://doi.org/10.1051/matecconf/201711602038 